\title{
Antioxidative Effect of Chelidonium majus Extract on Cultured NIH3T3 Fibroblasts Injured by Cadmium Chloride of Toxicant
}

\author{
Tae-Yoon Kim ${ }^{1}$ and Seung-Joo Jekal ${ }^{2}$ \\ Departments of ${ }^{1}$ Physical Therapy, ${ }^{2}$ Clinical Laboratory Science, Wonkwang Health Science University, Iksan 54538, Korea
}

\section{독성물질인 염화카드뮴으로 손상된 배양 NIH3T3 섬유모세포에 대한 애기똥풀 추출물의 항산화 효과}

\author{
김태윤 ${ }^{1}$, 제갈승주 $^{2}$ \\ 원광보건대학교 ${ }^{1}$ 물리치료학과, ${ }^{2}$ 임상병리학과
}

\begin{abstract}
The aim of this study was to evaluate the cytotoxicity of cadmium chloride $\left(\mathrm{CdCl}_{2}\right)$, toxicant, and the protective effect of Chelidonium majus (CM) extract on $\mathrm{CdCl}_{2}$-induced cytotoxicity in cultured $\mathrm{NIH} 3 \mathrm{~T} 3$ fibroblasts. Cell viability, the effect of butylated hydroxytoluene (BHT) against $\mathrm{CdCl}_{2}$, and the antioxidative effects including DPPH-free radical scavenging activity, superoxide anion-radical scavenging activity (SSA), and lactate dehydrogenase (LDH) activity were assessed. $\mathrm{CdCl}_{2}$ caused a significant dose-dependent decrease in cell viability, and XTT50 value was determined at $38.7 \mathrm{uM}$ of $\mathrm{CdCl}_{2}$. It was determined as highly-toxic by Borenfreund and Puerner' toxic criteria. BHT of antioxidant significantly increased cell viability severely damaged by $\mathrm{CdCl}_{2}$-induced cytotoxicity in these cultures. In the protective effect of $\mathrm{CM}$ extract on $\mathrm{CdCl}_{2}$-induced cytotoxicity, $\mathrm{CM}$ extract significantly increased cell viability, DPPH-free radical scavenging activity, SSA and inhibitory activity of LDH. From these results, it is suggested that oxidative stress is involved in the cytotoxicity of $\mathrm{CdCl}_{2}$, and $\mathrm{CM}$ extract showed protective efficacy on $\mathrm{CdCl}_{2}$-induced cytotoxicity via antioxidative effects. Conclusively, natural resources like $\mathrm{CM}$ extract may be a putative antioxidative agent for the detoxification or diminution of toxicity correlated with oxidative stress.
\end{abstract}

Keywords: Cytotoxicity, Antioxidative effect, Oxidative stress, Natural resources

This is an Open Access article distributed under the terms of the Creative Commons Attribution Non-Commercial License (http://creativecommons.org/licenses/by-nc/4.0) which permits unrestricted non-commercial use, distribution, and reproduction in any medium, provided the original work is properly cited.

Copyright ( 2016 The Korean Society for Clinical Laboratory Science. All rights reserved.
Corresponding author: Seung-Joo Jekal Department of Clinical Laboratory Science, Wonkwang Health Science University, 514 Iksan-daero, Iksan 54538, Korea Tel: 82-63-840-1215 Fax: 82-63-840-1219 E-mail: sjjei@wu.ac.kr

Received: February 1, 2016 Revised $1^{\text {st. }}$ February 25, 2016 Revised $2^{\text {nd: }}$ : February 29, 2016 Accepted: March 3, 2016
서 론

카드뮴은 은백색의 중금속류 일종으로 크롬과 같이 자연계에서 는 산소나 염소, 황과 결합하여 다양한 화합물을 형성하고 있다[1]. 카드뮴은 돌연변이원이면서도 독성이 강하기 때문에 이따이-이따 이병(itai-itai disease)으로도 잘 알려져 있다. 그 이유로는 1968년 일본 도마야현에 있는 미쯔이 제련공장의 폐광석에서 흘러나온 카
드뮴에 노출된 주민들에서 이의 독성으로 인해 골다공증을 비롯한 전신통증, 골연화증 폐암 및 신장기능장애와같은 후유증을 일으켰 던 대표적인 사례가 있었는데 특히 뼈나 근육의 통증을 호소함으로 서 붙여진 이름이다[2]. 카드뮴의 인체내 축적은 대부분 먹이사슬 에 의하여 이루어지며 일부는 피부접촉을 통해 피부병변 유발은 물 론, 그 밖에도 화석원료나 쓰레기 소각시에 분진에 의한 공기오염 에 의해서 호흡기를 통하여 흡입되기도 한다[3]. 공기중 $0.1 \mathrm{mg} / \mathrm{m}^{3}$ 
의 카드뮴 농도에 장기간 노출된 경우 폐병을 비롯한 신장병 및 골 다공증과 같은 질환의 위험율이 높아진다고 한다. 따라서 미국의 경우 $\mathrm{EPA}$ 에서는 공장에서 물이나 토양, 공기중으로 방출되는 카드 뮴 양을 엄격히 제한함으로서 국민건강에 기여하고 있다[4]. 카드 뮴의 독성이 강함에도 불구하고 이의 중독시 아직까지 독성기전은 물론, 효과적인 치료약제의 개발이 미흡한 상태에 있다[5].

최근, 카드뮴을 비롯한 몇몇 독성이 강한 크롬이나 수은과 같은 중금속류는 이들이 붕괴될 때 자유라디칼(free radicals)을 생성한 다고 알려지면서 이의 독성에 산화적 손상(oxidative stress)이 관 여하고 있다는 것이 제시된 바 있다[6]. 카드뮴의 독성에 관한 한 연 구에서 항산화제의 일종인 vitamin E가 카드뮴의 독성을 방어하였 다는 연구 결과가 보고됨에 따라 카드뮴의 독성과 산화적 손상간의 관련성이 제시되었다[7]. 따라서, 카드뮴 독성에 의한 치료적 접근 을 항산화 측면에서 시도할려는 연구가 이루어지고 있다[1].

한편, 천연물의 성분분석에 대한 연구에서 한약재를 비롯한 약 용식물의 성분 중에는 항산화를 비롯한 항염, 항암 및 항균과 같은 인체에 유효한 생리활성물질이 다량 함유되어 있다고 보고되고 있 다[8]. 이들 성분 중에는 flavonoid와 같은 페놀화합물(phenolic compound)을 비롯하여 anthocyanin과 같은 배당체들과 같은 다 양한 물질들이 알려져 있다[9].

식물 중 애기똥풀(Chelidonium majus, $\mathrm{CM}$ )은 양비귀과 (Papaveraceae)에 속하는 초본식물로서 우리나라 전국 각지의 햇 볕이 따스한 양지바른 곳이나 산기슭의 나무 주변 등과 같이 약간 시원하고 그늘진 곳에서 자생하고 있다. 흔히 $\mathrm{CM}$ 은 백굴체라고도 널리 알려져 있으며 대개 여름과 가을에 꽃을 비롯한 잎이나 줄기 를 채취하여 햇빛이 직접 들지 않은 서늘한 곳에서 말린 다음 이를 약재로 사용한다. $\mathrm{CM}$ 은 오래전부터 해독이나 이뇨는 물론 위궤양 이나 창종과 같은 염증성 병변 치료에 자주 사용되어 왔으며 그 밖 에도 완선이나 수종, 황달과 같은 질환 등에도 유효한 효능이 있는 것으로 알려져 있다[10]. CM에서는 palmitic acid를 비롯한 stigmasterol이나 taraxerol 성분들이 분리 정제되었으며, 그 밖에 도 berbenine이나 malic acid, polyphenol, flavonoid와 같은 성 분들이 함유되어 있다고 밝혀져 있다[11]. 특히, polyphenol이나 flavonoid와 같은 페놀성분들은 이의 분자구조에 다른 물질과의 결합력이 강한 수산기 $(-\mathrm{OH})$ 를 한 개 이상 가지고 있어 항산화나항 독 등에 뛰어난 효능이 있다고 알려져 있다[12].

근래 세포 배양기술이 발전함에 따라 배양 세포를 이용하여 병 변의 모델제작은 물론, 병인의 기전규명 및 치료적 접근을 위한 최 적의 도구로 자리잡고 있다[4]. 특히, 결합조직의 구성성분 하나인 섬유모세포는 비만세포나 형질세포와 함께 조직의 세포성분을 이 루고 있으며, 특히 콜라겐을 생성함으로서 피부의 찰과상이나 화상
과 같은 피부병변이나 또는 뼈의 인대나 힘줄 손상과 같은 외상으 로 인한 병변의 경우 이의 회복을 위하여 중요한 역할을 담당하고 있다[13].

본 연구는 천연소재를 이용한 병변의 치료물질에 대한 탐색이나 발굴을 위한 목적의 일환으로 독성물질인 염화카드뮴 $\left(\mathrm{CdCl}_{2}\right)$ 의 독 성분석과 함께 이에 대한 $\mathrm{CM}$ 추출물의 영향을 항산화 측면에서 조 사하기 위하여 배양 NIH3T3 섬유모세포를 재료로 시험관 내 분석 을 시행하였다.

\section{재료 및 방법}

\section{1. 실험재료}

NIH3T3 섬유모세포는 American Type Culture Collection (ATCC)에서 분양 받아 사용하였다.

\section{2. 약제 제조}

본 실험에 사용한 시약으로는 cadmium chloride $\left(\mathrm{CdCl}_{2}\right)$ 를 비롯한 butylayed hydroxytoluene (BHT), 1,1-diphenyl-2-picrylhydrazyl (DPPH), ethanol, phosphate buffered saline (PBS), fetal bovine serum (FBS), minimum essential medium (MEM), xanthine, nitroblue tetrazolium (NBT), hydrogen peroxide $\left(\mathrm{H}_{2} \mathrm{O}_{2}\right)$ 및 XTT는 Sigma사(Sigma Chemical Company, St. Louis, MO, USA)에서, LDH CytoTox detection kit는 Takara사(Takara Biochemical Company, Kangnam, Korea)에서 각각 구입하였 다. $\mathrm{CdCl}_{2}$ 의 제조는 $\mathrm{FBS}$ 가 없는 배양액을 사용하여 최종 농도가 각 각 $30 \mathrm{uM}, 50 \mathrm{uM}, 100 \mathrm{uM}$ 및 $150 \mathrm{uM}$ 의 저장액을 만들어 냉암소에 보관한 후 실험 직전 필요한 양을 배양액에 직접 첨가하여 사용하거 나 또는 필요농도로 희석하여 사용하였다.

XTT (2,3-bis-[2-methoxy-4-nitro-5-sulfophenyl]-2Htetrazolium-5-caboxanilide, disodium salt)는 실험 전날 PBS를 이용하여 $50 \mathrm{ug} / \mathrm{mL}$ 의 저장액을 제조한 후 사용하였다.

\section{3. 애기똥풀(Chelidonium majus, CM) 추출}

$\mathrm{CM}$ 은 7월경 전라북도 익산시 야산부근에서 채취하여 시에 위 치하고 있는 대학부설 생명자원과학연구소에서 확인 동정 후 사용 하였다. 채집한 전초는 세척한 후 통풍이 잘되고 서늘한 곳에서 말 린 다음 일정 길이로 잘라 냉암소에 보관하여 시료로 사용하였다. 시료추출을 위해 시료 $73.8 \mathrm{~g}$ 을 파쇄한 다음 시료의 3 배 정도의 증 류수와 함께 $1,000 \mathrm{~mL}$ 의 환저플라스크에 넣고 2시간 동안 가열하 였다. 위의 과정을 5 회 반복하여 추출한 액을 여과 후 $3,000 \mathrm{rpm}$ 에 서 30 분 동안 원침시켰으며, 원침 후 진공농축기에서 농축감압시 
켜 $4.3 \mathrm{~g}$ 의 시료를 얻었다. 이 때 수율은 $5.8 \%$ 로 나타났다.

\section{4. 세포 배양}

세포 배양은 Rim 등[8]의 방법에 의하여 배양용기로부터 효소 해리술에 의하여 세포를 분리하였다. 분리된 세포들은 일정 시간 동안 원침 후 $10 \% \mathrm{FBS}$ 가 함유된 $\mathrm{MEM}$ 배양액에 넣어 $1 \times 10^{5}$ cells/well의 밀도로 조절한 후 96 well plate에 삽주하였다. 삽주 된 세포들은 $36^{\circ} \mathrm{C}, 5 \% \mathrm{CO}_{2}$ 로 조절된 항온기 내에서 72 시간 동안 배양하였다.

\section{5. $\mathrm{CdCl}_{2}$ 처리}

$\mathrm{CdCl}_{2}$ 가 25 45 uM까지의 농도별로 각각 포함된 배양액에서 NIH3T3 섬유모세포를 72시간 동안 배양한 후 세포생존율을 대조 군과 비교 조사하였다.

\section{BHT의 항산화능 측정}

항산화제의 일종인 BHT의 항산화능의 조사를 위하여 활성산소 의 하나인 과산화수소 $\left(\mathrm{H}_{2} \mathrm{O}_{2}\right) 20 \mathrm{uM}$ 을 배양세포에 처리하기 2시간 전에 BHT가 각각 20 50 uM의 농도로 포함된 배양액에서 세포를 처리한 후 세포생존율을 대조군과 비교 조사하였다.

\section{7. $\mathrm{CdCl}_{2}$ 에 대한 $\mathrm{BHT}$ 의 영향}

$\mathrm{XTT}_{50}$ 값의 $\mathrm{CdCl}_{2}$ 를 배양 세포에 처리하기 2시간 전에 $\mathrm{BHT}$ 가 각각 $30 \mathrm{uM}$ 과 $50 \mathrm{uM}$ 의 농도로 포함된 배양액에서 세포를 배양한 다음 세포생존율을 양성대조군인 $\mathrm{CdCl}_{2}$ 의 처리군과 비교 조사하 였다.

\section{8. 애기똥풀(CM) 추출물 처리}

$\mathrm{CdCl}_{2}$ 에 대한 $\mathrm{CM}$ 추출물의 영향을 조사하기 위하여 배양 $\mathrm{NIH} 3 \mathrm{~T} 3$ 섬유모세포에 $\mathrm{CdCl}_{2} \mathrm{XTT}_{50}$ 값을 처리하기 2시간 전에 60 $\mathrm{ug} / \mathrm{mL}$ 와 $80 \mathrm{ug} / \mathrm{mL}$ 의 추출물 농도에서 세포를 처리한 다음 세포 생존율을 양성대조군인 $\mathrm{CdCl}_{2}$ 의 처리군과 비교 조사하였다. $\mathrm{CM}$ 추출물 분석농도는 Jung 등[14]에 의한 CM 추출물의 항산화능 (DPPH-free radical 소거능, xanthine oxidse 저해능) 분석 농도 인 $0.05 \mathrm{mg} / \mathrm{mL}-2.0 \mathrm{mg} / \mathrm{mL}$ 의 범위를 근거로 하여 이에 가장 근접 농도인 $0.06 \mathrm{mg} / \mathrm{mL}$ 와 $0.08 \mathrm{mg} / \mathrm{mL}$ 를 선정하여 분석하였다.

\section{9. 세포생존율 분석}

세포생존율의 분석은 Borenfreund와 Puerner [15]의 방법에 따랐다. 즉, 배양 세포에 농도별로 약제나 추출물을 일정 시간 처리 한 후 실험 당일 제조한 $50 \mathrm{ug} / \mathrm{mL}$ XTT를 well당 $100 \mathrm{uL}$ 씩 넣고 $36^{\circ} \mathrm{C}$ 로 조절된 항온기에서 4 시간 동안 배양하였다. 배양 완료 후 $\mathrm{DMSO}$ 를 넣고 일정시간 정치한 다음 varioskan flash ELISA reader (Thermofisher Scientific Company, Vantaa, Finland)로 $450 \mathrm{~nm}$ 에서 흡광도를 측정하였다. XTT50값의 산출은 회귀직선식 에 의하여 산정하였다.

\section{DPPH-자유라디칼 소거능 측정}

$\mathrm{DPPH}$-자유라디칼 소거능(DPPH-free radical scavenging activity)의 측정은 Blois [16]의 방법에 의하여 메탄올에 녹인 시료 에 $0.3 \mathrm{mM} \mathrm{DPPH}$ 메탄올용액 $100 \mathrm{uL}$ 를 넣고 실온에서 30 분간 처 리하였다. 처리 완료 후 varioskan flash ELISA reader (Thermofisher Scientific Company, Finland)로 $517 \mathrm{~nm}$ 에서 흡광도를 측정하였 다. 전자공여능은 시료첨가군과 시료무첨가군간의 차이를 시료무 첨가군에 의한 백분율로 나타냈으며, BHT의 활성을 비교군으로 하여 조사하였다.

\section{Superoxide anion-radical 소거능 측정}

Superoxide anion-radical 소거능의 측정은 nitroblue tetrazolium (NBT)환원 방법에 따라, 각 시료용액 $0.1 \mathrm{~mL}$ 와 $0.1 \mathrm{M}$ potassium phosphate buffer ( $\mathrm{pH} 7.5$ ) $0.4 \mathrm{~mL}$ 에 $0.4 \mathrm{mM}$ xanthine과 $0.24 \mathrm{mM} \mathrm{NBT}$ 를 가하여 $37^{\circ} \mathrm{C}$ 에서 20 분 동안 반응시 켰다. 반응이 완료된 후 $1 \mathrm{~N} \mathrm{HCl} 1 \mathrm{~mL}$ 를 가하여 반응을 정지시켜 반응액중에 생성된 superoxide anion radical 양을 varioskan flash ELISA reader (Thermofisher Scientific Company, Finland) 로 $560 \mathrm{~nm}$ 에서 흡광도를 측정하였다. 소거능 측정은 시료첨가군 과 무첨가군의 흡광도 감수율을 백분율로 나타냈다.

\section{LDH (lactate dehydrogenase) 활성 측정}

$\mathrm{LDH}$ 활성 조사를 위하여 배양 세포에 약제나 추출물을 농도별 로 처리한 다음 $250 \times \mathrm{g}$ 에서 15 분 동안 원침시켰다. 원침 완료 후 $50 \mathrm{uL}$ 의 상등액을 취한 다음 LDH CyTox detection kit의 반응용 액 $(0.05 \mathrm{U} / \mathrm{mL}) 50 \mathrm{uM}$ 를 넣은 다음 실온에서 30 분 동안 반응시켰 다. 반응 완료 후 $490 \mathrm{~nm}$ 에서 varioskan flash ELISA reader (Thermofisher Scientific Company, Finland)로 흡광도를 측정 하였으며 LDH 활성은 대조군에 대한 백분율로 표시하였다.

\section{3. 통계 처리}

자료분석은 Windows SPSS 프로그램 버전 18.0 (SPSS Inc., Chicago, USA)에 의하여 행하였으며 군간 차이값의 비교를 위하 여 ANOVA를 실시하였고 사후 검정은 Scheffe test에 의하였다. 


\section{결 과}

\section{1. $\mathrm{CdCl}_{2}$ 의 독성 효과}

$\mathrm{CdCl}_{2}$ 의 독성 조사를 위하여 배양 $\mathrm{NIH} 3 \mathrm{~T} 3$ 섬유모세포에 25 $45 \mathrm{uM}$ 농도의 $\mathrm{CdCl}_{2}$ 각각을 배양 세포에 72시간 동안 처리한 결 과, $\mathrm{CdCl}_{2}$ 는 농도처리에 따라 세포생존율을 유의하게 감소시켰으 며 $(p<0.001)$, 이 때 $\mathrm{XTT}_{50}$ 값은 $38.7 \mathrm{uM}$ 의 농도에서 나타났다 (Table 1).

\section{BHT의 항산화능 측정}

$20 \mathrm{uM}$ 의 $\mathrm{H}_{2} \mathrm{O}_{2}$ 만을 처리에서는 세포생존율이 대조군인 $100 \%$ (0.163 \pm 0.02$)$ 에 비하여 $39.9 \%$ (0.065 \pm 0.01$)$ 로 나타난 반면, 20 $\mathrm{uM}$ 농도의 BHT의 처리에서는 $46.0 \%(0.075 \pm 0.01)$ 로 $\mathrm{H}_{2} \mathrm{O}_{2}$ 만의 처리에 비하여 약간의 증가를 보였다. 또한, $30 \mathrm{uM}$ 과 $50 \mathrm{uM}$ 의 처 리에서는 세포생존율이 각각 $61.3 \%(0.100 \pm 0.01)$ 와 $74.8 \%$ $(0.122 \pm 0.02)$ 로 나타나 $\mathrm{H}_{2} \mathrm{O}_{2}$ 만의 처리에 비하여 모두 유의한 세 포생존율의 증가를 보였다 $(p<0.001)$ (Table 2$)$.

\section{3. $\mathrm{CdCl}_{2}$ 에 대한 $\mathrm{BHT}$ 의 영향}

$\mathrm{CdCl}_{2}$ 의 세포독성과 산화적 손상간의 상호관계를 알아보기 위 하여 $\mathrm{XTT}_{50}$ 값의 $\mathrm{CdCl}_{2}$ 를 배양 세포에 처리하기 전에 항산화제인 $\mathrm{BHT} 30 \mathrm{uM}$ 과 $50 \mathrm{uM}$ 의 농도를 세포에 각각 처리하였다. 그 결과 $\mathrm{CdCl}_{2}$ 만을 처리한 경우 세포생존율은 대조군인 100\% (0.175

Table 1. The cytotoxicity of $\mathrm{CdCl}_{2}$ on cultured $\mathrm{NIH} 3 \mathrm{~T} 3$ fibroblasts by XTT assay

\begin{tabular}{|c|c|c|c|}
\hline Incubation & \multicolumn{2}{|c|}{ XTT assay $(450$ nm) } & \multirow[b]{2}{*}{$p$} \\
\hline $\begin{array}{c}\text { Concentrations of } \\
\mathrm{CdCl}_{2} \text { (uM) }\end{array}$ & Mean $\pm S D$ & (\% of control) & \\
\hline Control* $^{*}$ & $0.196 \pm 0.05$ & 100 & \multirow{5}{*}{$*>^{0.001}>^{\ddagger}>$} \\
\hline $25^{\dagger}$ & $0.128 \pm 0.01$ & 65.3 & \\
\hline $35^{\ddagger}$ & $0.113 \pm 0.05$ & 57.7 & \\
\hline $45^{\S}$ & $0.072 \pm 0.02$ & 36.7 & \\
\hline $38.7\left(\mathrm{XTT}_{50}\right)$ & $0.098 \pm 0.04$ & 50.0 & \\
\hline
\end{tabular}

Table 2. The antioxidative effect of BHT on hydrogen peroxide $\left(\mathrm{H}_{2} \mathrm{O}_{2}\right)$

\begin{tabular}{lcccc}
\hline \multicolumn{1}{c}{ Incubation } & & \multicolumn{2}{c}{ XTT assay $(450 \mathrm{~nm})$} & \\
\cline { 1 - 2 } $\begin{array}{c}\text { Concentrations of } \\
\text { BHT (uM) }\end{array}$ & & Mean \pm SD & (\% of control) & \\
\hline Control $^{*}$ & & $0.163 \pm 0.02$ & 100 & \\
$20 \mathrm{uM} \mathrm{H}_{2} \mathrm{O}_{2}{ }^{\dagger}$ & & $0.065 \pm 0.01$ & 39.9 & \\
$20^{\ddagger}$ & $0.075 \pm 0.01$ & 46.0 & 0.001 \\
$30^{\S}$ & $0.100 \pm 0.01$ & 61.3 & \\
$50^{\|}$ & $0.122 \pm 0.02$ & 74.8 & \\
\hline
\end{tabular}

$0.02)$ 에 비하여 $37.1 \%(0.065 \pm 0.01)$ 로 나타난 반면, $30 \mathrm{uM}$ 과 50 $\mathrm{uM}$ 농도의 BHT의 처리에서는 각각 $59.4 \%$ (0.104 \pm 0.02$)$ 와 $64.0 \%$ (0.112 \pm 0.02$)$ 로 나타나 이는 $\mathrm{CdCl}_{2}$ 만의 처리에 비하여 모두 유의 하게 증가하였다 $(p<0.001)$ (Table 3).

\section{4. $\mathrm{CdCl}_{2}$ 의 독성에 대한 애기똥풀 $(\mathrm{CM})$ 추출물의 영향}

$\mathrm{CdCl}_{2}$ 의 세포독성에 대한 $\mathrm{CM}$ 추출물의 영향을 조사하기 위하 여 $\mathrm{XTT}_{50}$ 값의 $\mathrm{CdCl}_{2}$ 를 배양 $\mathrm{NIH} 3 \mathrm{~T} 3$ 섬유모세포에 처리하기 전에 $60 \mathrm{ug} / \mathrm{mL}$ 와 $80 \mathrm{ug} / \mathrm{mL}$ 의 $\mathrm{CM}$ 추출물을 전처리한 결과, $\mathrm{CdCl}_{2}$ 만의

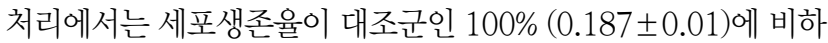
여 $41.2 \%(0.077 \pm 0.01)$ 로 나타난데 비하여 $60 \mathrm{ug} / \mathrm{mL} \mathrm{CM}$ 추출물 처리에서는 $56.1 \%(0.105 \pm 0.01)$ 로 나타나 $\mathrm{CdCl}_{2}$ 만의 처리에 비 하여 유의한 증가를 나타냈다 $(p<0.001)$. 한편, $80 \mathrm{ug} / \mathrm{mL}$ 추출물 처리에서는 세포생존율이 84.5\% (0.158 \pm 0.02$)$ 로 나타남으로서 $\mathrm{CdCl}_{2}$ 만의 처리에 비하여 유의한 증가를 나타냈다 $(p<0.001)$ (Table 4).

\section{DPPH-자유라디칼 소거능 측정}

$\mathrm{DPPH}-$ 자유라디칼 소거능(DPPH-free radical scavenging activity)을 측정하기 위하여 $60 \mathrm{ug} / \mathrm{mL}$ 와 $80 \mathrm{ug} / \mathrm{mL}$ 농도의 $\mathrm{CM}$ 추 출물 시료를 분석한 결과 $60 \mathrm{ug} / \mathrm{mL}$ 추출물 시료의 처리에서는 소 거능이 $28.5 \%$ 로 이는 대조군에 비하여 유의한 증가를 나타냈다 $(p<0.001)$. 또한, $80 \mathrm{ug} / \mathrm{mL}$ 추출물 처리에서는 $50 \%$ 로 나타나 이 역시 대조군에 비하여 유의한 증가를 보였다 $(p<0.001)$. 특히, 80

Table 3. The effect of BHT on the cytotoxicity induced by $\mathrm{CdCl}_{2}$ in cultured NIH3T3 fibroblasts

\begin{tabular}{|c|c|c|c|}
\hline Incubation & \multicolumn{2}{|c|}{ XTT assay $(450 \mathrm{~nm})$} & \\
\hline $\begin{array}{c}\text { Concentrations of } \\
\text { BHT (UM) }\end{array}$ & Mean $\pm S D$ & (\% of control) & \\
\hline Control* $^{*}$ & $0.175 \pm 0.02$ & 100 & \multirow{4}{*}{$\stackrel{0.001}{*>^{\neq 8}>}$} \\
\hline $\mathrm{CdCl}_{2}\left(\mathrm{XTT}_{50}\right)^{\dagger}$ & $0.065 \pm 0.01$ & 37.1 & \\
\hline $30^{\ddagger}$ & $0.104 \pm 0.02$ & 59.4 & \\
\hline $50^{\S}$ & $0.112 \pm 0.02$ & 64.0 & \\
\hline
\end{tabular}

Table 4. The protective effect of Chelidonium majus (CM) extract on $\mathrm{CdCl}_{2}$-induced cytotoxicity in cultured NIH3T3 fibroblasts

\begin{tabular}{lllll}
\hline \multicolumn{1}{c}{ Incubation } & & \multicolumn{2}{c}{ XTT assay $(450 \mathrm{~nm})$} & \\
\cline { 1 - 1 } $\begin{array}{c}\text { Concent. of } \mathrm{CM} \\
\text { extr. (ug/mL) }\end{array}$ & & Mean \pm SD (\% of control) & \\
\hline Control $^{*}$ & $0.187 \pm 0.01$ & 100 & \\
$\mathrm{CdCl}_{2}\left(\mathrm{XTT}_{50}\right)^{\dagger}$ & $0.077 \pm 0.01$ & 41.2 & 0.001 \\
$60^{\ddagger}$ & $0.105 \pm 0.01$ & 56.1 & $*^{\S}>^{\ddagger}>^{\dagger}$ \\
$80^{\S}$ & $0.158 \pm 0.02$ & 84.5 & \\
\hline
\end{tabular}


$\mathrm{ug} / \mathrm{mL}$ 의 추출물 시료에서 소거능은 비교군으로 사용한 $50 \mathrm{uM}$ $\mathrm{BHT}$ 활성값인 $68.7 \%$ 의 $50 \%$ 이상인 것으로 나타났다(Table 5).

\section{Superoxide anion-radical 소거능 측정}

$\mathrm{CM}$ 추출물 시료 $60 \mathrm{ug} / \mathrm{mL}$ 와 $80 \mathrm{ug} / \mathrm{mL}$ 에 대한 superoxide anion-radical 소거능에 있어서 $60 \mathrm{ug} / \mathrm{mL}$ 처리에서는 대조군에 비하여 $30.9 \%(p<0.001)$ 의 소거능을 나타냈으며, $80 \mathrm{ug} / \mathrm{mL}$ 에서 는 $48.0 \%(p<0.001)$ 의 소거능을 나타냈다. 특히, $80 \mathrm{ug} / \mathrm{mL}$ 의 추 출물 시료 처리에서는 비교군인 $50 \mathrm{uM} \mathrm{BHT}$ 소거능값인 $70.4 \%$ $(p<0.001)$ 의 $65 \%$ 이상의 높은 값을 나타냈다(Table 6).

\section{7. $\mathrm{LDH}$ 활성 측정}

$\mathrm{CdCl}_{2}$ 에 대한 $\mathrm{CM}$ 추출물의 LDH (lactate dehydrogenase) 활 성에 대한 영향을 조사하기 위하여 $60 \mathrm{ug} / \mathrm{mL}$ 와 $80 \mathrm{ug} / \mathrm{mL}$ 농도의 추출물을 분석한 결과 $\mathrm{XTT}_{50}$ 값의 $\mathrm{CdCl}_{2}$ 의 $\mathrm{LDH}$ 활성은 대조군에 비하여 $136.2 \%$ 로 높게 나타났다. 이에 비하여 $60 \mathrm{ug} / \mathrm{mL}$ 추출물 처 리에서는 $113.8 \%$ 로 나타나 $\mathrm{CdCl}_{2}$ 만의 처리에 비하여 유의한 활성 감소를 보였다 $(p<0.001)$. 또한, $80 \mathrm{ug} / \mathrm{mL}$ 추출물 처리에서는 $105.7 \%$ 로 나타나 이 역시 $\mathrm{CdCl}_{2}$ 만의 처리에 비하여 유의한 활성 감소를 보였다 $(p<0.001)$ (Table 7).

Table 5. DPPH-free radical scavenging activity of Chelidonium majus (CM) extract determined at a wavelength of $517 \mathrm{~nm}$

\begin{tabular}{|c|c|c|c|}
\hline \multirow{2}{*}{$\begin{array}{l}\text { Incubation } \\
\text { Concent. of } \mathrm{CM} \\
\text { extr. (ug/mL) }\end{array}$} & \multicolumn{2}{|c|}{$\begin{array}{c}\text { DPPH-free radical } \\
\text { scavenging activity }(517 \mathrm{~nm})\end{array}$} & \multirow{2}{*}{$p$} \\
\hline & Mean $\pm S D$ & (\% of control) & \\
\hline Control* & $0.214 \pm 0.02$ & 0 & \multirow{4}{*}{$+\underset{>\neq \S}{0.001}$} \\
\hline $50 \mathrm{uM} \mathrm{BHT}^{\dagger}$ & $0.067 \pm 0.01$ & 68.7 & \\
\hline $60^{\ddagger}$ & $0.153 \pm 0.01$ & 28.5 & \\
\hline $80^{\S}$ & $0.138 \pm 0.01$ & 35.5 & \\
\hline
\end{tabular}

Table 6. Superoxide anion-radical scavenging activity of Chelidonium majus (CM) extract determined at a wavelength of $560 \mathrm{~nm}$

\begin{tabular}{|c|c|c|c|}
\hline \multirow{2}{*}{$\begin{array}{l}\text { Incubation } \\
\text { Concent. of } \mathrm{CM} \\
\text { extr. (ug/mL) }\end{array}$} & \multicolumn{2}{|c|}{$\begin{array}{c}\text { Superoxide anion-radical } \\
\text { scavenging activity (560 nm) }\end{array}$} & \multirow{2}{*}{$p$} \\
\hline & Mean士SD & (\% of control) & \\
\hline Control* $^{*}$ & $0.152 \pm 0.02$ & 0 & \multirow{4}{*}{ 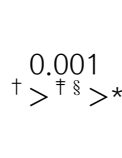 } \\
\hline $50 \mathrm{uM} \mathrm{BHT}^{\dagger}$ & $0.045 \pm 0.01$ & 70.4 & \\
\hline $60^{\ddagger}$ & $0.105 \pm 0.02$ & 30.9 & \\
\hline $80^{\S}$ & $0.079 \pm 0.01$ & 48.0 & \\
\hline
\end{tabular}

\section{고 찰}

염화카드뮴 $\left(\mathrm{CdCl}_{2}\right)$ 의 독성분석에 있어서 배양 $\mathrm{NIH} 3 \mathrm{~T} 3$ 섬유모 세포에 25 45 uM 농도의 $\mathrm{CdCl}_{2}$ 를 각각 72시간 동안 처리한 결과, 대조군에 비하여 세포생존율을 유의하게 감소시킴으로서 $(p<0.001)$, 세포독성을 나타냈다. 본 실험에서 처럼 $\mathrm{CdCl}_{2}$ 에 의한 세포생존율 의 감소는 $\mathrm{CdCl}_{2}$ 가 배양 $\mathrm{NIH} 3 \mathrm{~T} 3$ 섬유모세포에 세포독성이 있음을 말해주고 있으며, 이같은 독성은 $\mathrm{CdCl}_{2}$ 의 XTT50값이 $100 \mathrm{uM}$ 이하 인 $38.7 \mathrm{uM}$ 로 나타남으로서 Borenfreund와 Puerner [15]에 의한 독성판정기준에 의하여 고독성(highly-toxic)인 것으로 나타났다. 이들에 의한 독성판정기준을 보면 XTT50값이나 $\mathrm{MTT}_{50}$ 값이 100 $\mathrm{uM}$ 이하인 경우를 고독성(highly-toxic)으로 판정하였고, 100 $1,000 \mathrm{uM}$ 인 경우는 중간독성(mid-toxic)으로, $1,000 ~ 2,000 \mathrm{uM}$ 인 경우는 저독성(low-toxic)으로, 또한 2,000 uM 이상인 경우를 무독성(non-toxic)인 것으로 각각 판정하였다. 본 연구 결과는 Jung 등[7]에 의한 배양 NIH3T3 섬유모세포에 대한 카드뮴 독성에 대한 보고나, Son 등[5]에 의한 배양 섬유모세포에 대한 카드뮴의 독성 보고와도 일치하였다. 본 연구 결과에서와 같이 배양 $\mathrm{NIH} 3 \mathrm{~T} 3$ 섬유모세포에 대한 $\mathrm{CdCl}_{2}$ 의 독성효과에 대한 현상은 $\mathrm{CdCl}_{2}$ 에 의한 세포내 $\mathrm{DNA}$ 의 가교결합이나 RNA와 같은 핵산물질의 합성저해와 같은 가능성도 배제할 수는 없겠지만[17], 그 보다는 $\mathrm{CdCl}_{2}$ 의 독성 이 자유라디칼과 관련이 있어 그 결과 이의 산화적 손상으로 인해 세포생존율의 감소를 초래하였을 가능성이 클 것으로 생각된다[5]. 따라서, 본 연구에서는 $\mathrm{CdCl}_{2}$ 와 산화적 손상간에 대하여 조사하였 다.

한편, 본 연구에서 활성산소의 일종인 $\mathrm{H}_{2} \mathrm{O}_{2}$ 에 대한 $\mathrm{BHT}$ 의 항산 화능을 분석한 결과, $30 \mathrm{uM}$ 과 $50 \mathrm{uM}$ 농도의 BHT의 처리는 $20 \mathrm{uM}$ $\mathrm{H}_{2} \mathrm{O}_{2}$ 만의 처리에 비하여 모두 유의한 세포생존율의 증가를 보여 높은 항산화능을 나타냈다 $(p<0.001)$. BHT는 tocopherol이나 ascorbic acid와 같이 강력한 항산화제의 일종으로서 산화방지와 세포노화를 막아준다고 알려져 있다[18].

위에서 말한 바와 같이, 본 연구에서는 $\mathrm{CdCl}_{2}$ 의 독성과 산화적 손상간의 관련성 조사를 위하여 $\mathrm{CdCl}_{2}$ 에 대한 항산화제의 일종인

Table 7. LDH activity of Chelidonium majus (CM) extract on $\mathrm{CdCl}_{2}$-induced cytotoxicity determined at a wavelength of $490 \mathrm{~nm}$

\begin{tabular}{|c|c|c|c|}
\hline Incubation & \multicolumn{2}{|c|}{ LDH activity (490 nm) } & \multirow[b]{2}{*}{$p$} \\
\hline $\begin{array}{c}\text { Concent. of CM } \\
\text { extr. (ug/mL) }\end{array}$ & Mean \pm SD & (\% of control) & \\
\hline Control* & $0.174 \pm 0.04$ & 100 & \multirow{4}{*}{$\stackrel{0.001}{+{ }^{+*} \S}$} \\
\hline $\mathrm{CdCl}_{2}\left(\mathrm{XTT}_{50}\right)^{\dagger}$ & $0.237 \pm 0.06$ & 136.2 & \\
\hline $60^{\ddagger}$ & $0.198 \pm 0.03$ & 113.8 & \\
\hline $80^{\S}$ & $0.184 \pm 0.01$ & 105.7 & \\
\hline
\end{tabular}


$\mathrm{BHT}$ 의 영향을 분석하였다. 그 결과 $30 \mathrm{uM}$ 과 $50 \mathrm{uM}$ 농도의 BHT를 전처리한 결과 $\mathrm{CdCl}_{2}$ 만의 처리에 비하여 처리농도 모두에서 유의 한 세포생존율의 증가를 보였다 $(p<0.001)$. 위의 결과에서 처럼 항 산화제인 BHT에 의한 $\mathrm{CdCl}_{2}$ 의 독성방어는 $\mathrm{CdCl}_{2}$ 의 독성이 산화 적 손상과 관련되어 있음을 증명하고 있으며, 이는 Son 등[5]의 연 구에서 항산화제인 vitamin $\mathrm{E}$ 가 $\mathrm{CdCl}_{2}$ 독성을 감소하였다는 보고 와도 일치하였다.

한편, $\mathrm{CdCl}_{2}$ 의 독성에 대한 $\mathrm{CM}$ 추출물의 영향 분석을 위하여 60 $\mathrm{ug} / \mathrm{mL}$ 와 $80 \mathrm{ug} / \mathrm{mL}$ 의 $\mathrm{CM}$ 추출물 농도를 배양 세포에 전처리하였 다. 그 결과, $\mathrm{CdCl}_{2}$ 만의 처리에 비하여 추출물 처리농도 모두에서 유의한 세포생존율의 증가를 나타냈다 $(p<0.001)$. 이같은 결과는 $\mathrm{CM}$ 추출물이 $\mathrm{CdCl}_{2}$ 의 세포독성을 방어했음을 말해주고 있으며, 이는 또한 Son 등[10]에 의한 CM 추출물이 강독성의 유기수은의 세포독성을 방어하였다는 연구 결과와도 상통하였다. 본 결과에서 와 같이 $\mathrm{CdCl}_{2}$ 에 대한 $\mathrm{CM}$ 추출물의 방어효과는 Koizumi와 Waalkes [17]의 보고에서와 같이 카드뮴에 대한 CM 추출물의 항 독작용이나 또는 세포내 DNA나 RNA와 같은 핵산물질의 합성저 해에 대한 방어효과와 같은 일부 원인도 있겠지만, 그 보다는 CM 추출물의 항산화작용이 $\mathrm{CdCl}_{2}$ 의 산화적 손상을 방어한 결과로 생 각된다.

따라서 본 연구에서는 $\mathrm{CM}$ 추출물에 대한 항산화능을 조사하기 위 하여 DPPH-자유라디칼 소거능을 비롯한 superoxide anion-radical scavenging activity (SSA) 및 lactate dehydrogenase (LDH) 활성 을 조사하였다. 그 결과 $\mathrm{CM}$ 추출물은 항산화 분석 모두에서 유효한 효과가 있는 것으로 나타났으며, 특히 $80 \mathrm{ug} / \mathrm{mL} \mathrm{CM}$ 추출물 시료처 리에서는 DPPH-자유라디칼 소거능과 SSA에 있어서 비교군인 $\mathrm{BHT}$ 활성의 $50 \sim 65 \%$ 이상의 활성을 보여 BHT와 같은 항산화능을 나타냈다. 또한, 본 연구의 분석결과 중 $\mathrm{CM}$ 추출물은 유의한 $\mathrm{LDH}$ 활성 억제능을 보임으로서 자유라디칼의 막지질과산화에 대한 방 어능을 증명하였다. 따라서, 본 연구에서 행한 항산화능에 대한 분 석은 $\mathrm{CM}$ 추출물이 자유라디칼 제거를 위한 소거능을 가지고 있음 을 말해 주고 있으며 이같은 효능은 추출물 성분 중에 polyphenol, flavonoid와 같은 강력한 항산화 성분들에 의한 것으로 생각된다 [11]. 특히, polyphenol이나 flavonoid와 같은 페놀화합물은 항산 화능이나 항염, 항독과 같은 유효한 약리활성을 가지고 있음은 이미 잘 알려져 있다[19]. 따라서, $\mathrm{CM}$ 추출물과 같은 천연성분을 대상으 로 항산화에 대한 생리활성의 분석은 산화적 손상과 연관된 다양한 측면에서 지속적으로 연구가 이루어져야 할 것으로 생각된다.

\section{요 약}

본 연구는 배양 NIH3T3 섬유모세포를 재료로 독성물질인 염화 카드뮴 $\left(\mathrm{CdCl}_{2}\right)$ 의 세포독성과 이에 대한 애기똥풀(Chelidonium majus, $\mathrm{CM}$ ) 추출물의 방어효과를 조사하기 위하여 세포생존율 (cell viability)을 비롯한 $\mathrm{CdCl}_{2}$ 에 대한 $\mathrm{BHT}$ 의 영향 및 $\mathrm{DPPH}$-자 유라디칼 소거능, superoxide anion-radical scavenging activity (SSA), lactate dehydrogenase (LDH) 활성과 같은 항산화 효과를 분석하였다. 그 결과 $\mathrm{CdCl}_{2}$ 는 농도 의존적으로 배양 $\mathrm{NIH} 3 \mathrm{T3}$ 섬유모세포의 생존율을 유의하게 감소하였으며, $\mathrm{XTT}_{50}$ 값이 $38.7 \mathrm{uM}$ 로 나타나 Borenfreund와 Puerner의 독성판정기준 에 따라 고독성(highly-toxic)인 것으로 나타났다. 또한, 항산화제 인 BHT는 $\mathrm{CdCl}_{2}$ 의 독성으로 인하여 심하게 손상된 세포생존율을 유의하게 증가시켰다. 한편, $\mathrm{CdCl}_{2}$ 의 세포독성에 대한 $\mathrm{CM}$ 추출물 의 방어효과에서, $\mathrm{CM}$ 추출물은 $\mathrm{CdCl}_{2}$ 에 의하여 감소된 세포생존 율을 유의하게 증가시켰으며, 또한 DPPH-자유라디칼 소거능을 비롯한 SSA 및 LDH 활성 억제와 같은 항산화능을 나타냈다. 이상 의 결과에서 $\mathrm{CdCl}_{2}$ 의 독성에 산화적 손상이 관여하고 있으며, $\mathrm{CM}$ 추출물은 항산화 효과에 의하여 $\mathrm{CdCl}_{2}$ 의 세포독성에 대한 방어효 과를 나타냈다. 결론적으로, $\mathrm{CM}$ 추출물과 같은 천연소재는 산화적 손상과 관련된 독성의 제독 내지는 저감을 위한 항산화물질로서의 개발적 가치가 있다고 사료된다.

\section{Acknowledgements: None \\ Funding: None \\ Conflict of interest: None}

\section{References}

1. Jung JY, Oh SK, Park SH, Yoon MY, Yu YW, Rim YS, et al. Antioxidative effect of Ajuga multiflora BUNGE extract on chrominum trioxide, dermatitis inducer in cultured NIH3T3 fibroblasts. J Invest Cosmetol. 2014;10:21-26.

2. Waalkes MP, Poirier LA. In vitro cadmium-DNA interaction: Cooperativity of binding and competitive antagonism by calcium, magnesium and zinc. Toxicol Appl Pharmacol. 1984;75: 539-546.

3. Nomiyama K. Recent progress and perspective in cadmium health effects studies. Sci Total Environ. 1980;14:199-232.

4. Park ST, Choi MK, Lee KC, Cho KH, Jeon BH, Woo WH. Study on the effect of vitamin $\mathrm{E}$ on methylmercury in cultured spinal motor neurons. Kor J Oriental Med Pathol. 2000;14:7-10.

5. Son YW, Rim YS, Yu YW, Jung IJ. Effect of persimmon leaves extract on the cytotoxicity induced by cadmium of hair dye component. J Invest Cosmetol. 2012;8:9-15.

6. Kim MS, Seo YM, Park ST. Antioxidative effect of kaempferol 
on cultured human skin fibroblasts damaged by methylmercuric chloride. J Kor Soc People Plants Environ. 2010;13: 23-29.

7. Jung JY, Joe DY, Park SH, Seo YM, Protective effect of Rumex crispus L. extract on cultured NIH3T3 fibroblasts damaged by cadmium of environmetal pollutant. J Kor Soc People Plants Environ. 2014;17:15-21.

8. Rim YS, Song WS, Seo YM, Park ST, Kim SM. A study on the cytotoxic effects of several plant extracts on the cell viability and cell adhesion activity in cultured NIH3T3 fibroblast. Kor J Clin Lab Sci. 2010;42:116-124.

9. Li YL, Gan GP, Zhang HZ, Wu HZ, Li CL, Huang YP, et al. A flavonoid glycoside isolated from Smilax china L. rhizome in vitro anticancer cell lines. J Ethnophamacol. 2007;113:115-124.

10. Son YW, Oh SK, Choi YR, Park SH, Seo YM, Lee HJ, et al. Effects of Chelidonium majus extract on mercury-induced cytotoxicity and melanogenesis. J Invest Cosmetol. 2013;9:229-235.

11. Lenfeld J, Kroutil M, Marsalea E, Stavik J, Preininger V. Antiinflammatory avtivity of quatemary benzophenanthridine alkaroids from Chelidonium majus. Planta Med. 1981;43:161-165.

12. Rim YS, Seo YM, Son YW, Oh YL. Effect of Salicornia herbacea L. extract on protein synthesis and detoxicity in cultured C6 glioma cells. J Kor Soc People Plants Environ. 2012;15:149-154.

13. Wang EA. Bone morphogenetic protein (BMPs). Therapeutic potential in healing bony defects. Trends Biotechnol. 1993;11: 379-383.

14. Jung HM, Seo SJ, Kim JB, Kim NW, Joo EY. The study of physiological activities from Chelidonium majus var. asiaticum extract. J Invest Cosmetol. 2011;7:359-366.

15. Brenfreund E, Puerner JA. A simple quantitative procedure using monolayer culture for cytotoxicity assay (HTD/NR-90). J Tiss Cult Meth. 1984;9:7-9.

16. Blois MS. Antioxidant determination by the use of a stable free radical. Nature. 1958;26:1199-1200.

17. Koizumi T, Waalkes MP. Effect of zinc on the binding cadmium to DNA: assessment with testicular interstitial cell and calf thymus DNAs. Toxicol In Vitro. 1990;4:51-55.

18. Yamamoto M, Scima T, Uozumi T, Yamada K, Kawasaki T. A possible role of lipid peroxidation in cellular damages caused by cerebral ischemia and protective effect of alphatocopherol administration. Stroke. 1983;14:977-982.

19. De-Heredia JB, Torregrosa J, Dominguez JR, Peres JA. Kinetic model for phenolic compoud oxidation by fenton's reagent. Chemosphere. 2001;45:85-90. 